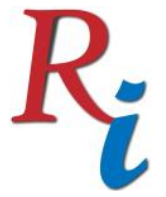

Asia Proceedings of Social Sciences

(APSS)

www.readersinsight.net/APSS

\title{
THE ROLE OF INTERNAL AUDIT UNITS IN OVERSEEING THE PERFORMANCE OF TREASURER DUTIES AT LEGAL ENTITY UNIVERSITY
}

\section{Ida Farida Adi Prawira*}

Department of Accounting, Faculty of Economy and Business Education Universitas Pendidikan Indonesia ida.farida@upi.edu

\section{Hanifa Zulhaimi}

Department of Accounting, Faculty of Economy and Business Education Universitas Pendidikan Indonesia hanifa.zulhaimi@upi.edu

\section{Widya Indriyani}

Student of Accounting Departement, Faculty of Economy and Business Education Universitas Pendidikan Indonesia

indriwidya@student.upi.edu

\section{Muhamad Naufal}

Student of Accounting Departement, Faculty of Economy and Business Education Universitas Pendidikan Indonesia

mnaufal30.mn@gmail.com

*Corrosponding author's Email: ida.farida@upi.edu

Peer-review under responsibility of 5th ${ }^{d}$ Asia International Conference 2019 Scientific Committee http://connectingasia.org/scientific-committee/

(C) 2019 Published by Readers Insight Publisher, lat 306 Savoy Residencia, Block 3 F11/1,44000 Islamabad. Pakistan,

editor@readersinsight.net

This is an open access article under the CC BY-NC-ND license (http://creativecommons.org/licenses/by-nc-nd/4.0/). 


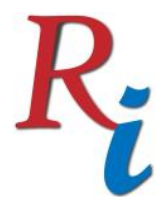

Asia Proceedings of Social Sciences

(APSS)

www.readersinsight.net/APSS

\section{Research High Iight s}

This study is important to do considering how important the role of internal audit is in an entity, and the role of internal audit is no exception in a Legal Entity University (LEU) which has specificities in its governance. The role of the internal audit is also very closely related to the supervision of the compliance of its employees in meeting the taxation obligations of the institution. Strong internal controls provide compliance with organizational policies, compliance with laws and regulations, protection against waste, fraud, and inefficiency, reduced organizational risk, reporting accuracy and consistency across business units and departments, documented evidence of compliance or non-compliance for internal audit, management controls (Puttick, 2008).

\section{Research Objectives}

This study measures how the internal audit units play a role in a Legal Entity University in fulfilling their tax obligations so that they fall into the category of compliant taxpayers. The Legal Entity University is a domestic tax subject because it does not meet the criteria of certain units of a government agency that are excluded as domestic subjects, as referred to in Article 2 paragraph (3) letter b of the Income Tax Law. In the case of a Legal Entity University having a business in the form of a separate legal entity, each separate legal entity has its own taxation obligations. With that status, the role of internal audit in LEU is very important, especially in overseeing the implementation of income tax deductions and collection.

\section{Methodology}

We entered the community of internal auditor units throughout Legal Entity University to conduct interviews with them, we were present at every activity they carried out and conducted interviews on their breaks during these meetings. however, the limited time and willingness of the auditors made us have to go to them directly to the campus where they work. 


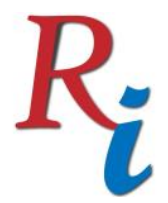

Asia Proceedings of Social Sciences

(APSS)

www.readersinsight.net/APSS

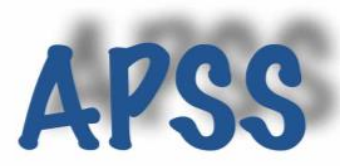

This study uses an interactive model in the analysis of interview data. Interactive models use 4 components, namely data collection, data reduction, data presentation, and conclusions or verification (Miles and Huberman, 1984: Sugiyono, 2007).

\section{Results}

Internal control is considered a management tool in the preservation of the assets and property of the organization and its continuing, it contributes in achieving the general objectives such as achieving the best possible profitability and protect the rights of shareholders, through the application of a strict system that includes control procedures implemented on the administrative and financial functions to verify the legitimacy and legality and in the efficiently the actual implementation of the company's activities, and ensure that all sections are committed with the legislations that govern the implementation of tasks by a pre-planned correct methodology (AlHarbi, 2017).

Legal Entity University Funding Assistance sourced from the State Revenue and Expenditure Budget (SREB) in the form of LEU Funding assistance and sourced from other than SREB received by LEU is the object of Income Tax. Whereas assets, grants, assistance and donations received by LEU are excluded as income tax objects as long as they meet the PMK 245 / PMK.03 / 2008 requirements. Thus, there are sources of funding received by LEU that are the objects of Income Tax and some are not the object of Income Tax. However, further receipts are subject to income tax. This provision makes the treasury's task more complex, so that making internal audit units must also be more intense in supervising their implementation.

Internal Auditor Units play an active role in overseeing financial reporting which also includes tax reporting. Internal auditors supervise the implementation of deductions and collection of Employee Income Taxes conducted by the Treasurer. however, the Treasurer's assignment has not been completed there. The treasurer must make proof of income tax withholding that has been carried out for one tax year and then given to all employees. For this task, unfortunately the internal auditor does not directly oversee its implementation. So there is no controversy from the internal auditor units carrying out the task of the treasurer, coupled with the limitations of the information system that can help the treasurer to make the 


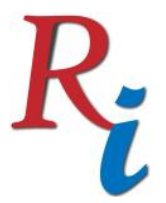

\section{Asia Proceedings of Social Sciences}

(APSS)

www.readersinsight.net/APSS

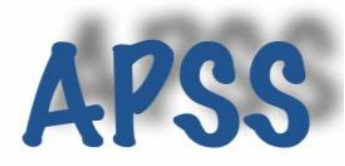

Proof of Withholding Taxes makes the Treasurer inconvenience because they have to make it manually entry.

\section{Findings}

Both internal audit units and treasurers have a very important role for an entity. In carrying out their respective roles in the Legal Entity University, internal auditor units must continue to provide assistance to the Treasurer, especially in carrying out their duties of cutting and collecting Income Taxes for all employees. it is not enough at the time of the deduction, but it also reaches the distribution of income tax deductions. Internal auditor units must ensure that the Income Tax Deduction has been received directly by all employees, however, this should not be a workload for the Treasurer or internal auditor units if LEU already has an integrated information system that makes it easy for all units to carry out their duties.

\section{Acknowledgement}

I take this opportunity to thank to Ministry of Research and Technology Directorate of Indonesian Higher Education to provide financial grant and also fully appreciate the reviewers of the Connecting Asia Research for constructive comments.

\section{References}

AlHARBI, Meshari Saad Awad. (2017). The effectiveness of The Implementation of Internal Control in Kuwaiti Shareholding Companies, International Journal of Academic Research in Accounting, Finance and Management Sciences, Vol.7 (4), pp 232-241.

Miles, M.B.and Huberman, M.A. (1984). Qualitative Data Analysis; A sourcebook of New Method. London: Beverly Hills, Sage Publications.

Puttick, V. E. (2008). The principles and practice of Audit: Business and Economics. Revised Edition. McGraw Hill High Education.

Sugiyono. (2007). Memahami Penelitian Kualitatif. Bandung: Alfabeta. 